\title{
DEVELOPING NEW STRAINS OF OKRA.
}

Masoud, A.M.*; Y.B. El-Waraky*; T.A. Shalaby** and M.H. Kasem*

* Veg. Res. Dept., Hort. Res. Int. Agric. Res. Center, Giza, Egypt

${ }^{* *}$ Horticulture Dept., Faculty of Agric., Kafrelsheikh Univ., Egypt

\section{ABSTRACT}

Great variations in plant vigor, productivity and pod characteristics are present in the local green and red cultivars of okra grown at Kafr El-Sheikh Governorate. Six strains of okra were obtained after five generations of inbreeding and selection from the local cultivars. The six selected strains as well as the original cultivars were evaluated during the summer season of 2006 at a private farm in Disuq district, Kafr El-Sheikh Governorate, for yield and horticultural characteristics. The experimental design was a complete randomized block with four replicates. The results indicated that the differences among the selected strains were highly significant for yield and all studied horticultural characteristics. Strain 5 was the tallest one, while, strain 3 had the largest values of most vegetative traits, therefore, it was the latest one. Strain 1 had the lowest values of vegetative traits and it produced the largest values of early and total yield as a number and weight of pods. Therefore, strains 1 and strain 2 surpassed all selected strains and the original cultivars in early and total pods weight. Therefore, strain 1 and strain 2 can be utilized as new cultivars or included in the breeding programs for improving okra production and quality in Egypt.

\section{INTRODUCTION}

Okra [Abelmoschus esculentus (L.) Moench.] is one of the important vegetable crops throughout tropical and sub-tropical regions. In Egypt, it is one of the most popular vegetables and considered a valuable source of calcium, iron and vitamins. It has been grown for its edible green pods which can be used as fresh, canned, frozen, or dried food.

Okra considered one of the partial allogamous crops, since its natural cross pollination exceeded $20 \%$ (Tindal, 1983), subsequently variation in its characteristics could be expected. Some characteristics of okra such as, plant height, branch number, color of veins and base of leaf, leaf lobes, pod type, pod color, pod pubescence, earliness proved its simply inheritance and high heritability (Martin et al., 1981 and Ariyo, 1990), as well as number of pods per plant which is very important.

Many researchers noticed high variations for the previous characteristics in the Egyptian local cultivars of okra (Abd El-maksoud et al., 1984; Damarany and Farag, 1994 and Hussein, 1994).

Pod yield represented as a number and weight of pods per unit area (square meter or feddan) is very important economic character, since selection has to be applied simultaneously to all of its components and quality characters (Falconer, 1960).

There are great variations in vegetative growth, earliness, productivity and pods quality in okra plants grown in Kafr Elsheikh governorate. Therefore, this study was conducted to select superior strains from the local cultivars through inbreeding and selection programs. 


\section{MATERIALS AND METHODS}

There are two local cultivars of okra, i.e., Balady Green and Balady Red. Great variations in plant vigor, earliness, and productivity and pod characteristics are present in okra plants grown in Kafr El-Sheikh Governorate. Selection of individual plants based on earliness, high number of pods, uniformity of plant phenotypic with moderate vegetative growth and uniformity of fruit color (pal green) and shape was carried out. Inbreeding of the selected plants was carried out for five successive generations and the pollination technique method described by Lee (1980) was followed. After five generations of inbreeding and selection, six strains were selected. The six selected strains as well as the original cultivars were evaluated during the summer season of 2006 at a private farm in Disuq district, Kafr El-Sheikh Governorate. The seeds were sown on April $5^{\text {th }}$. The experimental design was a complete randomized block with four replicates. Each experimental plot area was $12 \mathrm{~m}^{2}$, including 4 rows, each of $4 \mathrm{~m}$ length and $75 \mathrm{~cm}$ width and one plant per hill with $20 \mathrm{~cm}$ apart. The cultural practices were regularly done according to the general program of okra cultivation as reported to Egyptian Ministry of Agriculture.

\section{The following data were recorded:}

\section{Vegetative traits}

For studying the selected strains and cultivars morphology, ten plants were uprooted from each plot after 55 days from sowing, and the following data were recorded: 1) Stem length (cm), 2) number of branches per plant, 3) Leaf number per plant, 4) Plant fresh weight (g), 5) Plant dry weight (g) and 6) Leaf area per plant $\left(\mathrm{cm}^{2}\right)$. Leaf area was calculated according to the following formula:

Leaf area in $\mathrm{cm}^{2}=$ fresh weight of leaves/plant $(\mathrm{g}) \times$ leaf area of 20 discs / fresh weight of 20 disks $(\mathrm{g})$.

\section{Earliness traits}

Earliness was recorded as number of nodes to first flower and number of elapsed days from sowing to first flower anthesis.

\section{Early and total pods yield}

Early and total yield expressed as total number of pods per $\mathrm{m}^{2}$ and weight of pods (Kg per fed.) were recorded. Early yield was determined from the first four harvests, and fifteen harvests were recorded and calculated as the total yield.

\section{Pods characteristics}

At the $5^{\text {th }}$ picking, ten flowers were labeled in each plot, then after six days from anthesis as reported by Metwally and Etman (1992), these pods were picked and the following data were recorded: pod weight $(\mathrm{g})$, length $(\mathrm{cm})$, diameter $(\mathrm{cm})$, peduncle length $(\mathrm{cm})$ and peduncle weight $(\mathrm{g})$.

\section{Description of selected strains}

All observations determined by measurement, weighting or counting were done on 20 plants or parts taken from each of the 20 plants. All observations on the fruits were recorded on the young fruits at the time of commercial harvest. All observations on the stem, the leaf blade and the petiole were made on the $10^{\text {th }}$ to $15^{\text {th }}$ nodes of the main stem (UPOV, 1999). 


\section{Statistical Analysis}

Data were statistically evaluated by analysis of variance, and Duncan's multiple range test was used for the comparisons among the genotype means (Duncan, 1955).

\section{RESULTS AND DISCUSSION}

\section{Vegetative traits}

Data presented in Table (1) show that the original cultivars, i.e. Balady Red and Balady Green produced the tallest plants than the selected strains except strain 5 . The differences among the six selected strains of okra were significant for all studied traits; i.e., plant height, number of branches per plant, number of leaves per plant, plant fresh weight, plant dry weight and leaf area per plant. Strain 5 showed the largest values for stem length $(37.3 \mathrm{~cm})$ and number of leaves per plant (12.0), while, strain 1 produced the lowest values for all the studied vegetative traits, i.e., stem length $(25.0 \mathrm{~cm})$, number of branches per plant, number of leaves per plant (7.8), plant fresh weight $(75.0 \mathrm{~g})$, plant dry weight $(13.3 \mathrm{~g})$ and leaf area per plant $\left(1237.0 \mathrm{~cm}^{2}\right)$.

Table (1): Vegetative and flowering traits of the six selected strains and their original cultivars of okra after 55 days from sowing.

\begin{tabular}{|c|c|c|c|c|c|c|c|c|}
\hline \multirow[b]{2}{*}{$\begin{array}{l}\text { Strains } \\
\text { Cultivars }\end{array}$} & \multicolumn{6}{|c|}{ Vegetative traits } & \multicolumn{2}{|c|}{ Flowering traits } \\
\hline & $\& \begin{array}{c}\text { Stem } \\
\text { length } \\
(\mathrm{cm})\end{array}$ & $\begin{array}{l}\text { Brann- } \\
\text { ches / } \\
\text { plant } \\
\text { (no.) }\end{array}$ & $\begin{array}{c}\text { Leaves/ } \\
\text { plant } \\
\text { (no.) }\end{array}$ & $\begin{array}{l}\text { Plant } \\
\text { fresh } \\
\text { weight } \\
\text { (g) }\end{array}$ & $\begin{array}{l}\text { Plant dry } \\
\text { weight } \\
\text { (g) }\end{array}$ & $\begin{array}{l}\text { Leaf } \\
\text { area } \\
\text { /plant } \\
\left(\mathrm{cm}^{2}\right)\end{array}$ & $\begin{array}{l}\text { Nods to } \\
\text { first } \\
\text { flower } \\
\text { (no.) }\end{array}$ & $\begin{array}{c}\text { Days to } \\
\text { flowerin } \\
\text { g } \\
\text { (no.) }\end{array}$ \\
\hline Stra & $.0 \mathrm{~g}$ & $0.0 \mathrm{c}$ & & $75.0 \mathrm{e}$ & & $1237.0 \mathrm{c}$ & $3.3 \mathrm{~d}$ & $48.3 \mathrm{~h}$ \\
\hline Stra & $2.6 \mathrm{~d}$ & $0.8 \mathrm{bc}$ & $7.8 \mathrm{f}$ & $0 \mathrm{a}$ & $21.5 \mathrm{a}$ & $1791.6 \mathrm{a}$ & $3.3 \mathrm{~d}$ & $49.3 \mathrm{gh}$ \\
\hline Strai & $28.8 \mathrm{ef}$ & $3.0 \mathrm{a}$ & $11.5 \mathrm{cde}$ & $a$ & $19.5 \mathrm{ab}$ & $1919.5 \mathrm{a}$ & $5.8 \mathrm{a}$ & $67.8 \mathrm{a}$ \\
\hline Strai & $26.8 \mathrm{fg}$ & & $11.5 \mathrm{cde}$ & & $16.2 \mathrm{~d}$ & $1865.3 \mathrm{a}$ & $\mathrm{cd}$ & $5.3 \mathrm{f}$ \\
\hline Strai & $37.3 \mathrm{~b}$ & $2.5 \mathrm{a}$ & $12.0 \mathrm{~b}-\mathrm{e}$ & $a b$ & $19.7 \mathrm{ab}$ & $1802.2 \mathrm{a}$ & $4.8 \mathrm{abc}$ & 56.8 def \\
\hline Strain 6 & $33.0 \mathrm{~cd}$ & $2.8 \mathrm{a}$ & $10.5 \mathrm{e}$ & & $16.6 \mathrm{~d}$ & $1471.6 \mathrm{~b}$ & $5.0 \mathrm{ab}$ & 55.5 ef \\
\hline Bala & $39.5 \mathrm{ab}$ & $2.6 \mathrm{a}$ & $11.4 \mathrm{de}$ & $b c$ & $18.0 \mathrm{bcd}$ & $1764.7 \mathrm{a}$ & $4.9 \mathrm{abc}$ & $58.8 \mathrm{bc}$ \\
\hline Balady Red & $41.8 \mathrm{a}$ & $1.9 \mathrm{ab}$ & $19.3 \mathrm{a}$ & $112.6 \mathrm{a}$ & $20.5 a$ & $1855.6 \mathrm{a}$ & $4.5 \mathrm{bc}$ & $58.5 \mathrm{c}$ \\
\hline
\end{tabular}

Means designated by the same letter are not significantly different at 0.05 level, of probability, according to Duncan's test.

The highly significant differences among the selected strains of okra in the vegetative traits indicate that variations among the selected strains are due to genetic differences. Early work indicated high variations for vegetative traits of the Egyptian local cultivars of okra (Ragheb et al., 1994 and Abo Elkhar (2003).

\section{Flowering traits}

It is obvious from Table (1) that strains 1 and 2 were earlier in flowering than the original cultivars, while, strain 3 was later than the original cultivars. Differences among the six selected strains were highly significant for number of nodes to the first flower and number of days from sowing to flowering (Table 1). Strain 1 and strain 2 had the lowest number of nodes to the first flower with 3.3, while, strain 3 had the highest number of nodes to the first 
flower with 5.8. The number of days from sowing to flowering ranged from 48.3 days for strain 1 to 67.8 days for strain 3 .

Okra plants bearing the first flower on a lower node and need fewer days to flowering will be earlier than those bearing the first flower on a higher node and need more days to flowering (Metwally et al. 1988). Therefore, strains 1 and 2 were earlier than the other selected strains.

\section{Early and total pod yield}

Data in Table (2) indicate that each of strain 1, 2, 4 and 6 produced higher early yields than the Balady Green and Balady Red cvs., while, strain 3 was later than the original cultivars.

Table (2): Early and total yield of the six selected strains and the two original cultivars of okra.

\begin{tabular}{|l|c|c|c|c|}
\hline \multirow{2}{*}{$\begin{array}{l}\text { Cultivains } \\
\text { \&urs }\end{array}$} & \multicolumn{2}{|c|}{ Early yield } & \multicolumn{2}{c|}{ Total yield } \\
\cline { 2 - 5 } & $\begin{array}{c}\text { No. of pods per } \\
\text { plant }\end{array}$ & $\begin{array}{c}\text { Pods weight } \\
\text { (kg/fed.) }\end{array}$ & $\begin{array}{c}\text { No. of pods per } \\
\text { plant }\end{array}$ & $\begin{array}{c}\text { Pods weight } \\
\text { (kg/fed.) }\end{array}$ \\
\hline Strain 1 & $11.8 \mathrm{a}$ & $931.4 \mathrm{a}$ & $33.0 \mathrm{a}$ & $5224.8 \mathrm{a}$ \\
\hline Strain 2 & $11.7 \mathrm{a}$ & $871.8 \mathrm{~b}$ & $29.0 \mathrm{~b}$ & $4301.3 \mathrm{~b}$ \\
\hline Strain 3 & $0.0 \mathrm{~g}$ & $0.0 \mathrm{~h}$ & $11.1 \mathrm{~h}$ & $1613.9 \mathrm{~h}$ \\
\hline Strain 4 & $2.5 \mathrm{~b}$ & $332.2 \mathrm{c}$ & $16.0 \mathrm{e}$ & $2122.3 \mathrm{~d}$ \\
\hline Strain 5 & $0.9 \mathrm{e}$ & $140.7 \mathrm{f}$ & $20.6 \mathrm{c}$ & $3308.6 \mathrm{c}$ \\
\hline Strain 6 & $2.0 \mathrm{c}$ & $234.1 \mathrm{~d}$ & $16.5 \mathrm{~d}$ & $1940.2 \mathrm{f}$ \\
\hline Balady Green & $0.6 \mathrm{f}$ & $90.4 \mathrm{~g}$ & $13.8 \mathrm{~g}$ & $1777.1 \mathrm{~g}$ \\
\hline Balady Red & $1.5 \mathrm{~d}$ & $217.5 \mathrm{e}$ & $14.9 \mathrm{f}$ & $1971.7 \mathrm{ef}$ \\
\hline
\end{tabular}

Means designated by the same letter are not significantly different at 0.05 level, of probability, according to Duncan's test.

The data elicit that the differences were highly significant for early pods yield, as a number and weight of pods. Strain 1 and 2 produced the highest values for number of pods per plant with 11.8 and 11.7, respectively. In addition strain 1 and 2 produced the highest values for pods weight with 931.4 and $871.8 \mathrm{~kg}$ per fed., respectively. The superiority of strains 1 and 2 for early yield as a number and weight may be due to its early flowering compared with the other strains.

As for the total pods yield, i.e. number of pods per plant and pod weight $(\mathrm{kg} / \mathrm{fed}$.), (Table 2) show that most of the strains surpassed the original cultivars. Strain 1 produced the largest values of total pods yield as a number and weight with 33.0 pods per plant and $5224.8 \mathrm{~kg}$ per fedden, respectively. However, strain. 3 produced the lowest values of total pods yield as a number and weight with 11.1 pods per plant and $1613.9 \mathrm{~kg}$ per fedden, respectively. The differences among different selected strains for total pods yield were highly significant. It is clear from the data that, strain 1 surpassed all strains for total pods yield. The superiority of the strain 1 may be due to the higher number of pods produced per plant compared with the other strains. Many investigators noticed high variations for pods yield of the Egyptian local cultivars of okra (Abd El-hafez and Salah, 1977; Damarany and Farag, 1994; Hussein, 1994; Ragheb et al., 1994; Abo El-khar, 2003).

\section{Pod characteristics}

The important characteristics that determine the quality of okra is pod length, diameter, weight and color. Data presented in Table (3) show that pod 
length ranged from $3.1 \mathrm{~cm}$ for strain 3 to $5.9 \mathrm{~cm}$ for strain 2. Pods diameter ranged from $1.5 \mathrm{~cm}$ for strain 2 to $1.8 \mathrm{~cm}$ for strain 3 and 5 . The length of peduncle of pods ranged from $3.3 \mathrm{~cm}$ for strain 6 to $5.0 \mathrm{~cm}$ for strain 2 . Average pod weight was 3.3 and $5.1 \mathrm{~g}$ for strain 6 and strain 5 , respectively. Strain 2 had red pods, while the other strains had pal green pods (Fig. 1).

It is clear from the pod characteristics that the differences among the selected strains and the two original cultivars of okra were highly significant. These data confirm that these strains are genetically different.

Many investigators noticed high variations for pod characteristics of the Egyptian cultivars of okra (Damarany and Farag, 1994; Hussein, 1994; and Abo El-khar, 2003).

Table (3): Pods characteristics of the six selected strains and the two original cultivars of okra after 6 days from anthesis.

\begin{tabular}{|l|c|c|c|c|c|}
\hline $\begin{array}{l}\text { Strains } \\
\text { Cultivars }\end{array}$ & $\begin{array}{c}\text { Average pod } \\
\text { length } \mathbf{( c m )}\end{array}$ & $\begin{array}{c}\text { Average pod } \\
\text { diameter (cm) }\end{array}$ & $\begin{array}{c}\text { Average pod } \\
\text { weight (g) }\end{array}$ & $\begin{array}{c}\text { Average } \\
\text { peduncle } \\
\text { length (cm) }\end{array}$ & $\begin{array}{c}\text { Average } \\
\text { peduncle } \\
\text { weight (g) }\end{array}$ \\
\hline Strain 1 & $5.1 \mathrm{~b}$ & $1.7 \mathrm{~b}$ & $3.84 \mathrm{~d}$ & $4.8 \mathrm{a}$ & $2.46 \mathrm{a}$ \\
\hline Strain 2 & $5.9 \mathrm{a}$ & $1.5 \mathrm{~d}$ & $3.82 \mathrm{~d}$ & $5.0 \mathrm{a}$ & $2.37 \mathrm{a}$ \\
\hline Strain 3 & $3.1 \mathrm{f}$ & $1.8 \mathrm{a}$ & $4.31 \mathrm{~b}$ & $4.0 \mathrm{~d}$ & $1.73 \mathrm{c}$ \\
\hline Strain 4 & $4.9 \mathrm{bc}$ & $1.6 \mathrm{c}$ & $3.97 \mathrm{~cd}$ & $4.3 \mathrm{c}$ & $1.57 \mathrm{~d}$ \\
\hline Strain 5 & $5.3 \mathrm{~b}$ & $1.8 \mathrm{a}$ & $5.08 \mathrm{a}$ & $4.2 \mathrm{~cd}$ & $1.63 \mathrm{~cd}$ \\
\hline Strain 6 & $3.9 \mathrm{e}$ & $1.8 \mathrm{a}$ & $3.25 \mathrm{e}$ & $3.3 \mathrm{f}$ & $1.64 \mathrm{~cd}$ \\
\hline Balady Green & $4.3 \mathrm{de}$ & $1.8 \mathrm{a}$ & $4.15 \mathrm{bc}$ & $3.9 \mathrm{~d}$ & $1.64 \mathrm{~cd}$ \\
\hline Balady Red & $4.5 \mathrm{~cd}$ & $1.6 \mathrm{c}$ & $4.07 \mathrm{c}$ & $4.5 \mathrm{~b}$ & $2.05 \mathrm{~b}$ \\
\hline
\end{tabular}

Means designated by the same letter are not significantly different at 0.05 level of probability, according to Duncan's test.

\section{Description of the selected strains and original cultivars}

Data presented in Table (4) show that the differences among the six selected strains and the original cultivars of okra.

Fig. (1): Size, Shape and color after six days from anthesis of the selected strains. 
Masoud, A.M. et al.

Table (4): Description of the six selected strains and two original cultivars of okra according to UPOV guideline.

\begin{tabular}{|c|c|c|c|}
\hline Characteristics ${ }^{1}$ & $\begin{array}{l}\text { Character } \\
\text { states }\end{array}$ & $\begin{array}{c}\text { Selected strains and } \\
\text { original cultivars }\end{array}$ & Note ${ }^{* *}$ \\
\hline 1. Plant: degree of branching & $\begin{array}{l}\text { Week } \\
\text { Medium } \\
\text { Strong }\end{array}$ & $\begin{array}{r}2,4, \text { B.R } \\
3,5,6, \text { B.G }\end{array}$ & $\begin{array}{l}3 \\
5 \\
7\end{array}$ \\
\hline 2. Plant: height & $\begin{array}{l}\text { Short } \\
\text { Medium } \\
\text { Tall }\end{array}$ & 5, B.G, B.R & $\begin{array}{l}3 \\
5 \\
7\end{array}$ \\
\hline 3. Stem: diameter & $\begin{array}{l}\text { Small } \\
\text { Medium } \\
\text { Large }\end{array}$ & $2,3,4,6,5$, B.R & $\begin{array}{l}3 \\
5 \\
7\end{array}$ \\
\hline 4. Stem: color * & $\begin{array}{l}\text { Green } \\
\text { Red }\end{array}$ & $2,3,4,5,6$, B.R & $\begin{array}{l}1 \\
2\end{array}$ \\
\hline 5. Stem: intensity of color & $\begin{array}{l}\text { Light } \\
\text { Medium } \\
\text { Dark }\end{array}$ & $3,4,5,6$, B.R & $\begin{array}{l}3 \\
5 \\
7\end{array}$ \\
\hline $\begin{array}{l}\text { 6. Stem: number of nodes (up to and including the } \\
\text { first flowering node) }\end{array}$ & $\begin{array}{l}\text { Few } \\
\text { Medium } \\
\text { Many }\end{array}$ & $2,4,5,6, \underset{3}{B} \cdot G, B$ R & $\begin{array}{l}3 \\
5 \\
7\end{array}$ \\
\hline 7. Leaf blade: size & $\begin{array}{c}\text { Small } \\
\text { Medium } \\
\text { Large }\end{array}$ & $\begin{array}{c}1,2,4,5,6, B \text { R } \\
\text { B.G, }\end{array}$ & $\begin{array}{l}3 \\
5 \\
7 \\
\end{array}$ \\
\hline 8. Leaf blade: depth of lobbing & $\begin{array}{l}\text { Shallow } \\
\text { Medium } \\
\text { Deep }\end{array}$ & 1, 2, 4, 5.6, B.G & $\begin{array}{l}3 \\
5 \\
7\end{array}$ \\
\hline 9. Leaf blade: denotation of margin & $\begin{array}{l}\text { Week } \\
\text { Medium } \\
\text { Strong }\end{array}$ & $12,3,4,5,6, B . G$ & $\begin{array}{l}3 \\
5 \\
7\end{array}$ \\
\hline 10. Leat blade: color between veins & $\begin{array}{c}\text { Green } \\
\text { Red }\end{array}$ & $1,2,3,4,5,6$, B.G, B.R & $\begin{array}{l}1 \\
2 \\
\end{array}$ \\
\hline 11. Leaf blade: intensity of color between veins & $\begin{array}{l}\text { Light } \\
\text { Međium } \\
\text { Dark }\end{array}$ & $1,2,3,4,5,6$, B.G, B.R & $\begin{array}{l}3 \\
5 \\
7 \\
\end{array}$ \\
\hline 12. petiole: length & $\begin{array}{l}\text { Short } \\
\text { Medium } \\
\text { Long }\end{array}$ & $1,3,4,5,6, B . G$ & $\begin{array}{l}3 \\
5 \\
7\end{array}$ \\
\hline 13. Petiole: diameter & $\begin{array}{c}\text { Small } \\
\text { Medium } \\
\text { Large }\end{array}$ & $1,2,3,4,5,6$, B.G, B.R & $\begin{array}{l}3 \\
5 \\
7 \\
\end{array}$ \\
\hline 14. Flower: size & $\begin{array}{c}\text { Small } \\
\text { Medium } \\
\text { Large }\end{array}$ & $1,5,6,6$, B.G & $\begin{array}{l}3 \\
5 \\
7\end{array}$ \\
\hline 15. Fower: color & $\begin{array}{l}\text { Green } \\
\text { Red }\end{array}$ & $\begin{array}{l}1,3,4,5,6, B . G \\
2, \text { B.R }\end{array}$ & $\begin{array}{l}1 \\
2\end{array}$ \\
\hline 16. Flower: intensity of color & $\begin{array}{l}\text { Light } \\
\text { Medium } \\
\text { Dark }\end{array}$ & $\begin{array}{c}\text { 1, B.G, B.R, } \\
2,3,4,5\end{array}$ & $\begin{array}{l}3 \\
5 \\
7\end{array}$ \\
\hline 17. Fruit: diameter of young fruit (at mid length) & $\begin{array}{c}\text { Small } \\
\text { Medium } \\
\text { Large }\end{array}$ & 4, B.G, B.R & $\begin{array}{l}3 \\
5 \\
7\end{array}$ \\
\hline Characteristics' & Character states & $\begin{array}{l}\text { Selected strains and } \\
\text { original cultivars }\end{array}$ & Note ${ }^{* *}$ \\
\hline 18. Fruit: surface between ridges & $\begin{array}{l}\text { Concave } \\
\text { Flat } \\
\text { Convex }\end{array}$ & $\begin{array}{l}2,3,4,5,6, B R \\
1, \text { B.G }\end{array}$ & $\begin{array}{l}3 \\
5 \\
7 \\
\end{array}$ \\
\hline 19. Fruit: shape of apex & $\begin{array}{l}\text { Narrow } \\
\text { Acute } \\
\text { Broad }\end{array}$ & $\begin{array}{c}1,2,4,5 \\
6, \stackrel{6}{6}, \text { B.R }\end{array}$ & $\begin{array}{l}1 \\
2 \\
3 \\
\end{array}$ \\
\hline 20. Fruit: number of locules & $\begin{array}{c}\text { Five } \\
\text { More than five }\end{array}$ & $2,3,4,5,6$, B.G, B.R & $\begin{array}{l}1 \\
2 \\
\end{array}$ \\
\hline 21. Fruit: thickness of carpel & $\begin{array}{l}\text { Thin } \\
\text { Medium } \\
\text { Thick }\end{array}$ & $4,5, \begin{array}{l}1,2 \\
3, G\end{array}$ & $\begin{array}{l}3 \\
5 \\
7 \\
\end{array}$ \\
\hline 22. Fruit; length of mature fruit & $\begin{array}{l}\text { Short } \\
\text { Medium } \\
\text { Long }\end{array}$ & 4, 5, $\begin{array}{l}3,6 \\
\text { B.G, } \\
1,2\end{array}$ & $\begin{array}{l}3 \\
5 \\
7\end{array}$ \\
\hline 23. Fruit: diameter of mature fruit (at mid length) & $\begin{array}{c}\text { Small } \\
\text { Medium } \\
\text { Large }\end{array}$ & $2,3,4,5,{ }_{1}^{6}$ B.G & $\begin{array}{l}3 \\
5 \\
7 \\
\end{array}$ \\
\hline 24. Time of flowering & $\begin{array}{l}\text { Early } \\
\text { Medium } \\
\text { Late }\end{array}$ & $\begin{array}{r}1,2 \\
4,5 \\
3,6, \text { B.G, B.R } \\
\end{array}$ & $\begin{array}{l}3 \\
5 \\
7 \\
\end{array}$ \\
\hline 25. Time of commercial harvest & $\begin{array}{l}\text { Early } \\
\text { Medium } \\
\text { Late }\end{array}$ & $\begin{array}{r}\text { 1, } \\
\text { 4, } 5 \\
3,6, \text { B.G, B.R }\end{array}$ & $\begin{array}{l}3 \\
5 \\
7\end{array}$ \\
\hline
\end{tabular}

(1) To asses distinctness, uniformity and stability, the characteristics and their states as given in the table of characteristics should be used.

$\left.{ }^{*}\right)$ characteristics that should be used on all lines in every growing period over which the examinations are made and always be included in the lines descriptions, except when the state of expression of a preceding characteristic or regional environmental conditions render this impossible.

$\left({ }^{\star *}\right)$ notes (number, for the purposes of electronic data processing, are given opposite the states of expression for each characteristic. 


\section{REFERENCES}

Abd El-hafez, A.A. and M. Salah (1977). Comparative studies on exotic and strains of Egyptian local cultivars characters in okra. J. Agric. Sci. Mansoura Univ. 2: 247-258.

Abd El-maksoud, M.A.; R.M. Helal and M.H. Mohamed (1984). Heritability estimates and correlation studies of six economic characters in okra. Annals of Agric. Sci., Ain Shams Univ. 29: 439-452.

Abo El-khar, Y.Y. (2003). Efficiency of selection with inbreeding on improving some characteristics in the balady cultivar of okra. M.Sc. Alex. Univ., Fac. Agric., Egypt.pp:111.

Ariyo, O.J. (1990). Variation and heritability of fifteen characters in okra [Abelmoschus esculentu (L.) Moench.]. Trop. Agric. 67: 213-216.

Damarany, A.M. and I.A. Farag (1994). An evaluation of growth, yield and quality of some okra cultivars and strains under Assiut conditions. Assiut J. Agric. Sci. 25: 57-70.

Duncan, B.D. (1955). Multiple ranges and multiple F-test. Biometrics, 11: 142.

Falconer, D.S. (1960). Introduction to quantitative genetics. The Ronald Press Co. N.Y. 365p.

Hussein, H.A. (1994). Variation, heritability and response to selection in okra. Assiut. J. Agric. Sci. 25: 193-202.

Lee, J.A. (1980). Cotton in: Fehr, W.R. and H.H. Hadley (eds.) Hybridization of crop plants. Amer. Soci. Agron.and Crop Sci. Soci. Amer., Publi. Madison, Wisconsin, USA.

Martin, F.M.; A.M. Rhodes, M. Ortiz and F. Diaz (1981). Variation in okra. Euphytica, 30: 697-705.

Metwally, E.I and A.A. Etman (1992). Diallel cross analysis of yield and related traits of okra in winter season under plastic house condition. J.Agric. Res. Tanta Univ. 18:135-147.

Metwally, E.I.; B.I. El-Sawy and R.M. Khalil (1988). Heterosis and nature of gene action studies on yield and related traits of okra Hibiscus esculentus (L) Moench. J. Agric. Res. Tanta Univ. 14: 1088-1105.

Ragheb, W.S.; H.A. El-Shamma and H.A. Ghazal (1994). Inheritance of yield and pod characters in okra. Zagazig J. Agric. Res. 21: 1785-1795.

Tindal, H.D. (1983). Vegetable in the tropics, P. 325, MaComillan Press. London.

UPOV. 1999. Guidelines for the conduct of test for distinctness, uniformity and stability, okra [Ablmoschus esculentus (L.) Moench.]. International Union for the protection of new varieties of plants, TG/167/3, Geneva. 
Masoud, A.M. et al.

استباط سلالات جليده من البامية

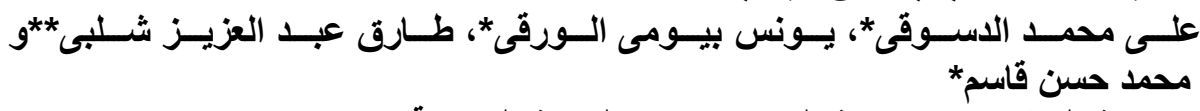
"بحوث الخضر - معهل بحوث البساتين- مركز البحوث الزراعية

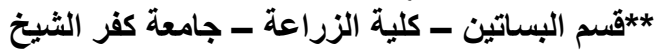

توجد اختلافات مورفولوجية كبيرة فى طبيعة النمو و التبكير و المحصول وكذللك في مو اصفات

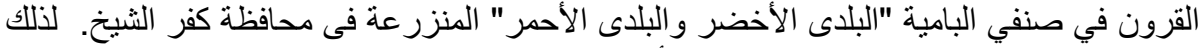

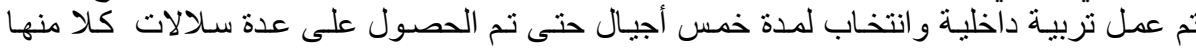

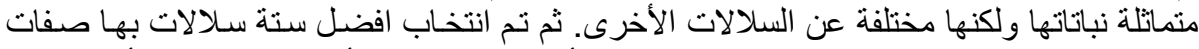

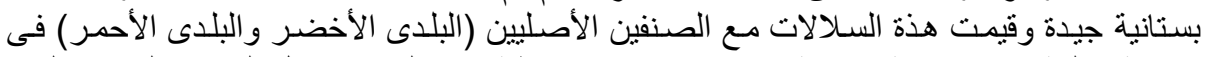

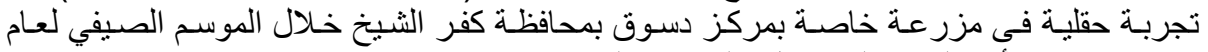

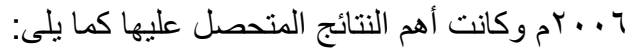

كانت الاختلافات عالية المعنوية لصفات الندو النيات الخضري والمحصول وكذلك مواصفات القرون بين

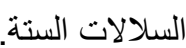

كانت السـلالة (0) أطول السـلالات أمـا السـلالة (ب) فقد أعطـت اكبر القيم فـى معظم الصـفات

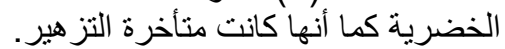

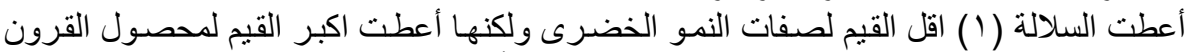

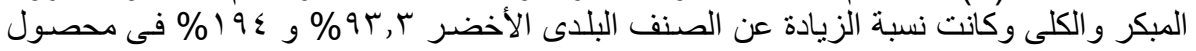
القرون المبكر و الكلى، على النى التو الزئي

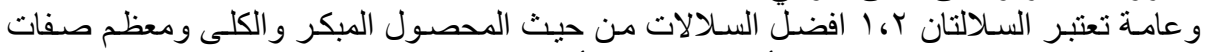

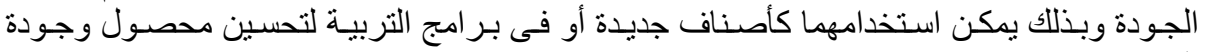

